\title{
Estimation of gillnet selectivity for Tor tambra captured in Lirik River, Merangin Regency, Jambi Province
}

\author{
Muhammad Natsir Kholis ${ }^{1}$, Sulaeman Martasuganda ${ }^{2}$, Mohd. Yusuf Amrullah ${ }^{1}$, Jaliadi ${ }^{3}$ \\ ${ }^{1}$ Faculty of Fisheries, Muara Bungo University, Indonesia. \\ ${ }^{2}$ Faculty of Fisheries and Marine Science, IPB University, Indonesia. \\ ${ }^{3}$ Faculty of Fisheries and Marine, Teuku Umar University, Indonesia. \\ *Corresponding author: kholis2336@gmail.com
}

\author{
ARTICLE INFO \\ Keywords: \\ Gillnet; Lirik River; \\ Merangin Regency; \\ Selectivity; Tor tambra. \\ How to cite: \\ Kholis, M. N., \\ Martasuganda, S., \\ Amrullah, M. Y., \& Jaliadi. \\ (2020). Estimation of gillnet \\ selectivity for Tor tambra \\ captured in Lirik River, \\ Merangin Regency, Jambi \\ Province. Tomini Journal of \\ Aquatic Science, 1(1), 29- \\ 36
}

ABSTRACT

\begin{abstract}
Fishing gear selectivity is the condition of a fishing gear that can catch fish the target of catching and escaped other fish so that selectivity has an essential role for fisheries managers who make regulations regarding the mesh size. The purpose of this study is to estimate the selectivity of gillnet fishing gear on Semah fish (Tor tambra). The method used in this research is the experimental fishing method. The results showed that the gillnet in the Lirik River has an estimated value of selectivity to Semah fish ( $T$. tambra) mesh size of 1.5 inches at a length of $48.59 \mathrm{~cm}$ and a mesh size of 2 inches at a length of 64.78 $\mathrm{cm}$. Semah fish ( $T$. tambra) which have a length far below the estimated value of selectivity will be able to pass through the net without getting caught (escaped), and fish that have a length far above the estimated value of selectivity will be entangled.
\end{abstract}

\section{INTRODUCTION}

Lirik River is a Tembesi tributary located in East Jangkat District. Lirik River has a length of \pm 15 $\mathrm{km}$ width $\pm 8 \mathrm{~m}$ and a depth of $\pm 5 \mathrm{~m}$. The headwaters of this river have ecological types of fast to medium flowing waters, and their characteristics are sandy and rocky and surrounded by rice fields and community plantations. The river is a potential fishing area for fishing operations. The fish that are excellent are the Semah fish (Tor tambra). The fish saplings are abundant in shallow water, and the adults are found in deep river basins (Haryono, 2008; Subagja et al., 2009). At present, Semah fish is an endangered fish species, due to high fishing activities and an unfavorable environment (Kottelat et al., 1993; Haryono, 2008; Subagja et al., 2009). Alverson et al. (1994) stated that the use of non-selective fishing gear caused a decline in fishery resources.

The gillnet is not a new fishing technology for fishers as the material is easy to obtain, technically easy to operate, economically actual affordable, and selective to fish size (Tawari, 2013). The 
solution to maintaining the conservation of Semah fish is the use of a size and species selective fishing gear.

Fishing gear selectivity is a condition where the gear can catch fish targets for catching and can pass other fish (Martasuganda \& Wahju, 2011). According to Sparre and Venema (1999), the selectivity of fishing gear must be considered if you want to estimate the actual fish size composition in the fishing area. Also, the selectivity of fishing gear has an essential role for fisheries managers who make regulations regarding the size of the net, conservation areas, and the optimal amount of exploitation of fisheries resources (Balasubramanian et al., 2016). The purpose of this study is to analyze the estimated selectivity of gillnet on Semah fish ( $T$. tambra).

\section{MATERIAL AND METHODS}

The research was carried out from January to April 2018 in the Lirik River, District of East Jangkat, Merangin Regency, Jambi Province. The method used in this research is the experimental fishing method. The fishing area is located at three coordinate points (S $2^{\circ} 32^{\prime} 7^{\prime \prime}$; $\mathrm{E}$

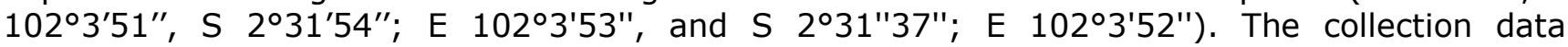
techniques were measuring the total morphometric length ( $T L)$, fork length (FL), opercular girth (Go), maximum body girth (Gm), and maximum girth ( $\mathrm{G}$ max).

Materials as well as objects in this study are two units of gillnet with the same size but diverse mesh sizes and catch composition. The tools used are stationery, questionnaire, calipers, meter, and digital camera. Data analysis of the calculation of gillnet estimation using the Holt model for two mesh sizes, with the following formula:

$$
S_{L}=\exp \left[-\frac{(L-L m)^{2}}{2 * s^{2}}\right]
$$

Where SL is the optimum length of fish that can be caught, and $\mathrm{s}$ is the standard deviation and normal distribution. SL or selectivity is a fraction, that is $0<S L \leq 1$ (Sparre \& Venema, 1999). Data analysis procedures to create the selectivity curve are as follows:

1. Calculating the logarithm of the ratio for each overlapping length group:

$$
\begin{aligned}
& \mathrm{Y}=\left(\frac{\mathrm{Ca}}{\mathrm{Cb}}\right) \\
& \text { Where: } \\
& \mathrm{Y}=\text { frequency length }(\mathrm{cm}) \\
& \mathrm{Ca}=\text { fish caught in the mesh size of } 3.81 \mathrm{~cm} \\
& \mathrm{Cb}=\text { fish caught in the mesh size of } 5.08 \mathrm{~cm}
\end{aligned}
$$

2. Analyzing the regression to the logarithm of the ratio ( $y=\ln (\mathrm{Cb} / \mathrm{Ca}$ ) to the midpoint of the fish length interval $(x=L)$ and determine $a$ and $b$ :

$$
\begin{aligned}
& \mathrm{Ln}\left[\frac{\mathrm{Ca}}{\mathrm{Cb}}\right]=\mathrm{a}+\mathrm{b} * \mathrm{~L} \\
& \text { Where: } \\
& \mathrm{a}=\text { fish caught in a smaller net }\left(\mathrm{FL} \mathrm{cm}^{-1}\right) \\
& \mathrm{b}=\text { fish caught in a bigger net }(\mathrm{FL} \mathrm{cm}-1) \\
& \mathrm{L}=\text { fish length interval (class length) }(\mathrm{cm})
\end{aligned}
$$

3. Calculating the estimated selection factors:

$$
\begin{aligned}
& \mathrm{SF}=\frac{-2 * \mathrm{a}}{\mathrm{b} *(\mathrm{ma}+\mathrm{mb})} \\
& \text { Where: } \\
& \mathrm{SF}=\text { selection factor } \\
& \mathrm{ma}=\text { mesh size } 3.81 \mathrm{~cm} \\
& \mathrm{mb}=\text { mesh size of } 5.08 \mathrm{~cm}
\end{aligned}
$$


4. Calculating standard deviations on both sizes
$\mathrm{Lma}=\mathrm{SF} * \mathrm{ma} \quad \mathrm{Lmb}=\mathrm{SF} * \mathrm{mb}$
$S^{2}=\frac{-2 * a(m b-m a)}{b^{2} *(m a-m b)}=S F * \frac{m b-m a}{b}$
Where:
Lma $=$ the optimum length range of fish caught in the mesh size of $3.81 \mathrm{~cm}$
$\mathrm{Lmb}=$ optimum length range of fish caught in mesh size of $5.08 \mathrm{~cm}$
$\mathrm{S}^{2}=$ standard deviation
$\mathrm{a}=$ intercept
$b=$ slope

\section{RESULTS AND DISCUSSION}

Identification and fishing methods. Gillnet used by the river fishermen has a mesh size of 1.5 inches $(3.81 \mathrm{~cm})$ and 2 inches $(5.08 \mathrm{~cm})$. In general, gillnet used to catch Semah fish ( $T$. tambra) is still very traditional with minimal technology, and technical operation does not use any boat. Construction of gillnet fishing gear operated in Lirik River is rectangular with the size of ML $7 \mathrm{~m}$ and MD $1.98 \mathrm{~m}$. The length of the float rope, sinker rope, top ris float, and under ris rope is $9.52 \mathrm{~m}$. The 29 units of buoys were made of foam, while the 37 units of the sinkers were made of tin. Noticeably, the construction and design of the fishing gear can be seen in Figure 1.

Fishing gear models and sizes differ in each fishing operation area. According to Andriyani et al. (2015), the gillnet in Tanjung Balai Asahan has a length of $10 \mathrm{~m}$, width 1.5, and mesh size 1.3 inch. The webbing is made of nylon net and green. The size of the ship has a length of $5 \mathrm{~m}$ and a width of $1.5 \mathrm{~m}$ with a weight of 3 GT. Meanwhile, according to Kholis et al. (2018), characteristics of the gillnet in PPI Muara Angke are the fishing gear floats using mini purse seine buoys, and they do not have specific types of target catch. Muara Angke PPI gillnets have a mesh size of $5.08 \mathrm{~cm}$ or 2 inches. The primary material of the net body is PA monofilament, with a net length of $1500 \mathrm{~m}$ and has a depth of $15 \mathrm{~m}$. The rope type is S to the left, with PE and PP material.

The method of operating the gillnet equipment conducted by the river fishermen does not use a fishing fleet. The number of fishers operating gillnets in the river are 2-4 people. Fishing was operated depending on the tidal conditions of the river. Habitually, fishers haul at $03.00 \mathrm{pm}$ (Western Indonesian Time) when the water recedes due to when high tide is hazardous to fishing. The fishermen generally prepare the whole thing that will be used for gear setting when they arrived in the fishing ground, such as checking the net, preparing a place/container for catching, checking the float and sinker ropes.

The setting gear was conducted by swimming down the river, then stretching the net, and tying the hauling rope to sticks or a wooden pole alongside the river. The net will be stretched entirely on the surface goes with the water flow. The net was pulled down at $03.35 \mathrm{pm}$ (Western Indonesian Time), with the hauling duration ranging from 10-20 minutes per unit.

Hauling begins by releasing the hauling rope tied to a stake or a wooden pole, then continue with the pulling out of the net by swimming along the river following the water flow toward the end of the river. The catches are immediately released from the net by twirling the fishing gear slowly to avoid broken net, and if tangled, the net will be cut. The duration of gillnet operation in the river about 1 hour 30 minutes. It means that if the setting is completed at $03.35 \mathrm{pm}$ (Western Indonesian Time), then the hauling is finished at $05.05 \mathrm{pm}$ (Western Indonesian Time). The fishers usually set and haul 2-3 times a day. 


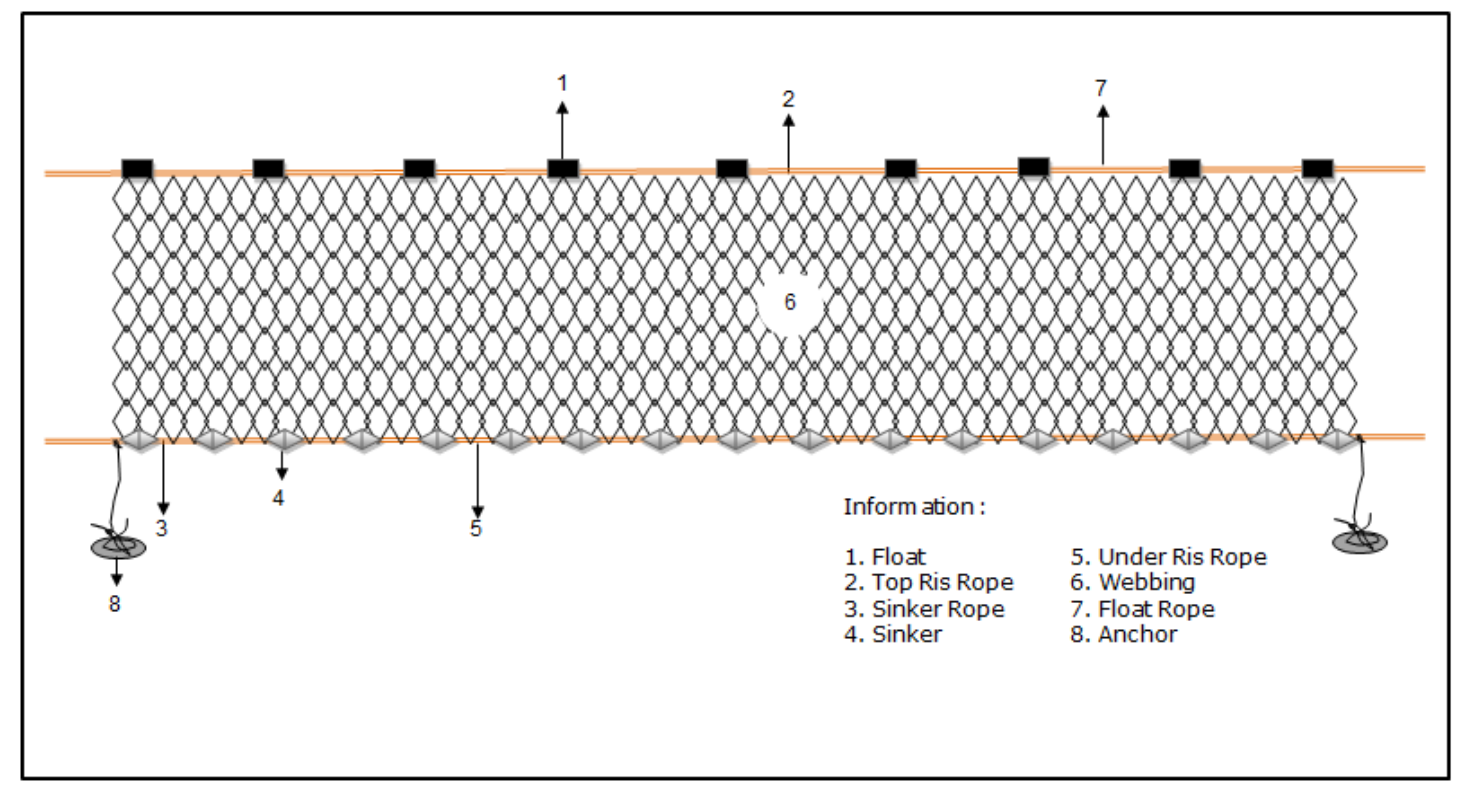

a

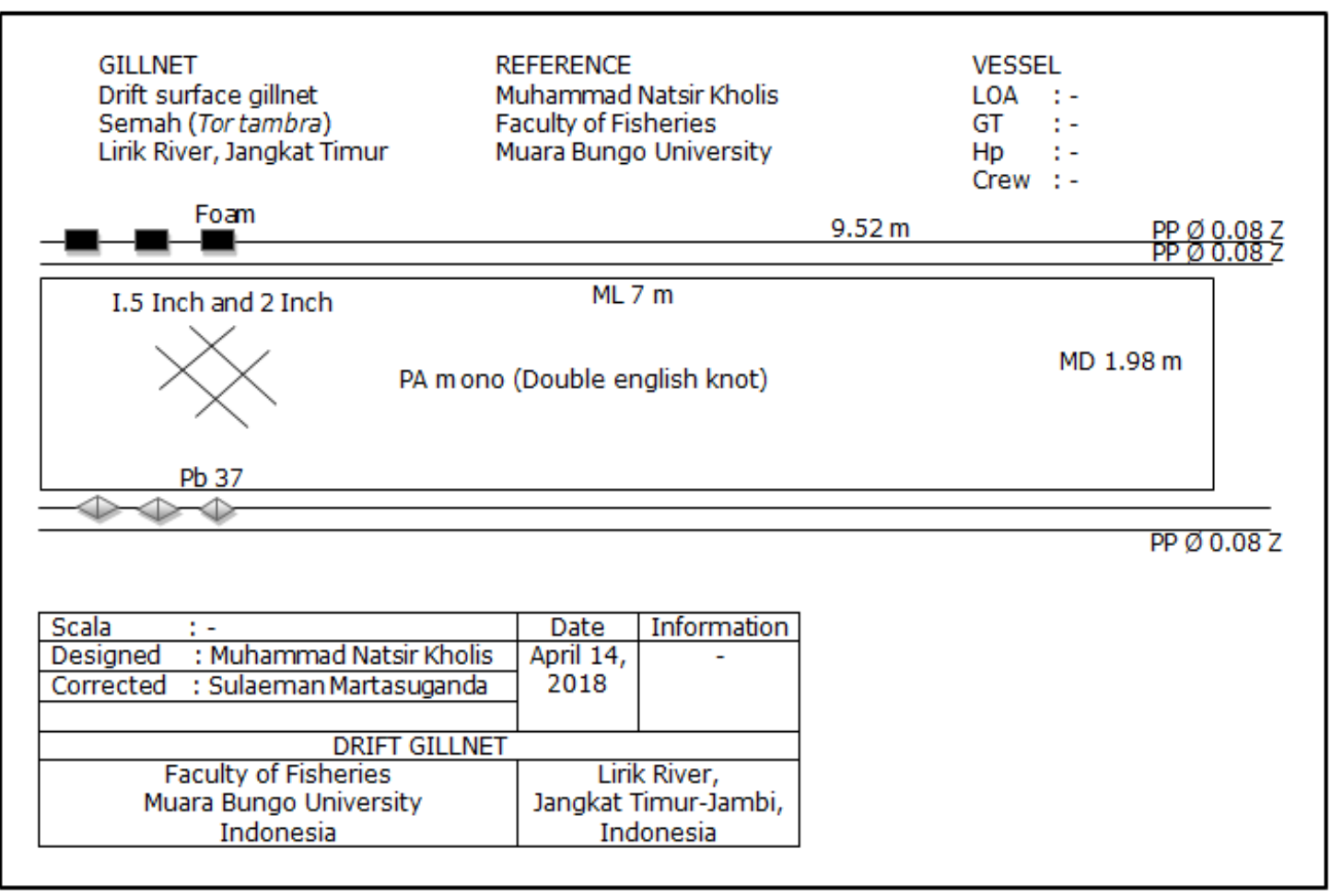

$b$

Figure 1. a. Gillnet construction b. Gillnet design in Lirik River

Catch composition. The amount of fish caught during the 36 experiments is 245 . The catch consists of 4 species (T. tambra, Barbodes lateristriga, Mystus nemurus, Hemibagrus nemurus) and two families (Cyprinidae and Bagridae). Most catches are dominated by 129 Semah fish ( $T$. tambra), followed by 78 Kepyur fish (B. lateristriga), 26 Baung fish (M. nemurus), and 12 Baung Putih fish ( $H$. nemurus). The composition of the catch using gillnet in the Lirik River can be seen in Figure 2. 


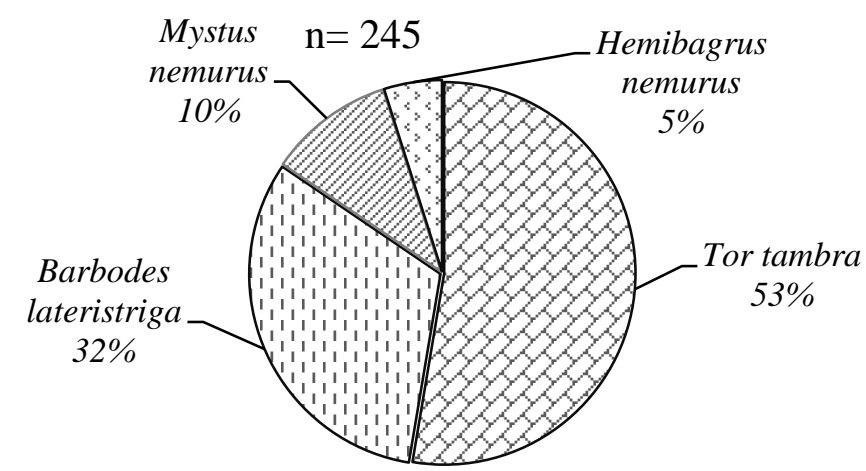

Figure 2. Composition of catch using 1.5 inch and 2 inch mesh size gillnets in Lirik River

Frequency distribution of Semah Fish (Tor tambra). The composition of the gillnet catch conducted by the Lirik River fishermen shows that the Semah fish ( $T$. tambra) is the most caught with a percentage of $53 \%$ of the total catches (Figure 2 ), it shows the gillnets have a selective level to species as $1 / 2$ of the total catch is a target fish. According to Govender and Al-Qufi (2019), gillnet has a selective criterion: high catch efficiency and support to recruit juveniles. Figure 3 shows the frequency distribution of Semah fish ( $T$. tambra) caught at the smallest 1.5 inch mesh size at $41-52 \mathrm{~cm}$ and $76-87 \mathrm{~cm}$ at four heads and the highest at $53-64 \mathrm{~cm}$ at 22 fish while the frequency distribution of Semah fish in a 2 inch mesh size has the lowest length ranging from $29-40 \mathrm{~cm}$ by one fish and the highest by $65-75 \mathrm{~cm}$ a total of $21 \mathrm{fish}$.

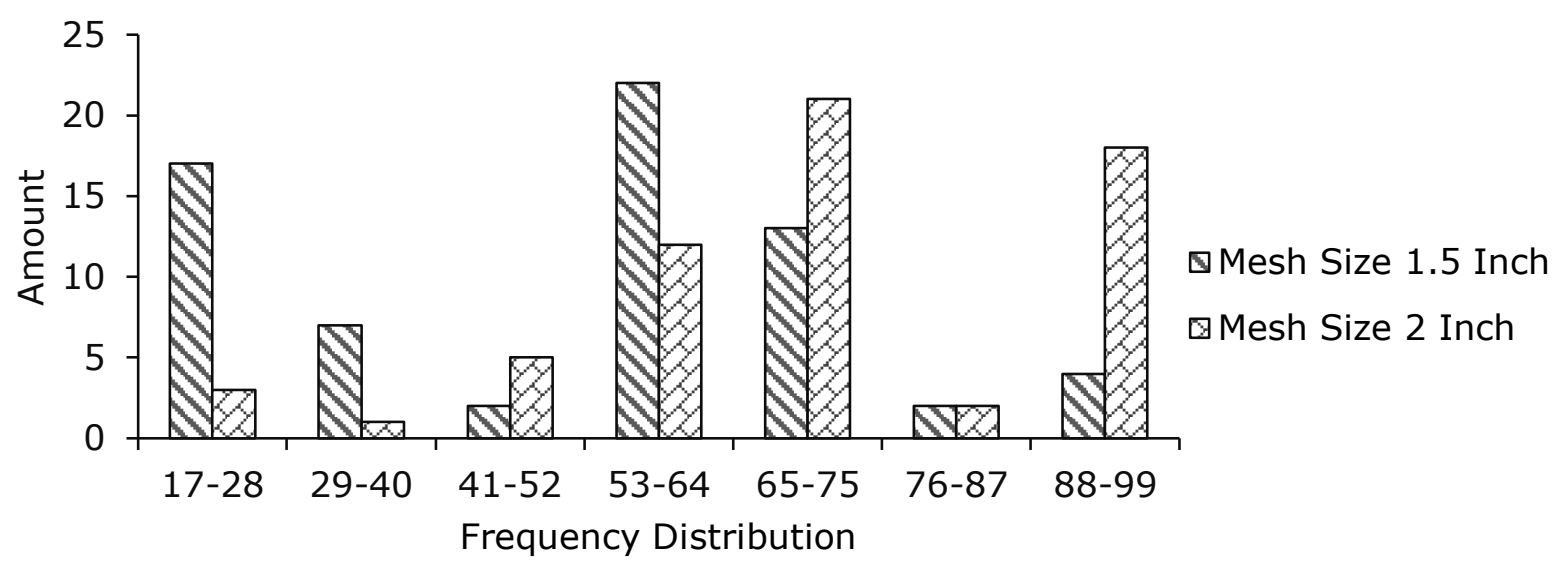

Figure 3. Table frequency distribution of Semah fish (Tor tambra) using gillnet by Lirik River fishermen

The frequency distribution of a type of fish has many factors, one of which is the habitat of the fish where the fish live. Semah fish from the genus Tor are classified as endemic fish that inhabit the waters of rivers and lakes upstream. Its distribution is in the Sundanese Exposure, which includes: Java, Sumatra, and Kalimantan (Weber \& de Beaufort, 1962) and Thailand (Smith, 1945). In South Sumatra and Jambi, these fish are known as Semah and are found in the waters of lakes (Ranau Lake and Kerinci Lake) and rivers (Musi and Batanghari rivers in the upstreammountain range). The habitat is water that flows with a rocky or graveled substrate. Tiller fish found in shallow waters and adult fish found in deep river basins. This fish species in its habitat has high economic value as consumption fish (Subagja et al., 2009)

Gillnet selectivity. Estimation of fishing gear selectivity has many methods approaches, including the method of Ishida (1962), Kitahara (1971), Matsuoka (1995), Millar \& Holst (1997), and Sparre \& Venema (1999). In this study using the method of Sparre and Venema (1999) using two different sizes of mesh gillnet for one particular species of fish.

The gillnet selectivity curve (Figure 4) shows that the fishing gear with a mesh size of $3.81 \mathrm{~cm}$ has optimum selectivity ( $\mathrm{SaL}=1$ ) in fish with a length (Lma) of $48.59 \mathrm{~cm}$. While fishing gear with a mesh size of $5.08 \mathrm{~cm}$ has optimum selectivity ( $\mathrm{SbL}=1)$ in fish with a length $(\mathrm{Lmb})$ of 
$64.78 \mathrm{~cm}$, Semah fish (T. tambra), which have a length far below the optimum value (Lma and $\mathrm{Lmb}$ ) will be able to pass through the net, and fish that have a length far above the optimum value will be tangled up. Similarly as according to Putri et al. (2018), the value of gillnet selectivity in Semarang waters with a mesh size of 1.4 inches and 3.5 inches L50\% (restrained fraction), namely $15.5 \mathrm{~cm}$ (Lma) $\mathrm{cm}$ and $24 \mathrm{~cm}$ (Lmb). Fish with a length extreme under the L50\% value will be able to pass through the net without getting tangled up, and fish that have a length far upper the $\mathrm{L} 50 \%$ will be entangled. Comparison of mesh size can also determine selectively against a decent size of fish caught, according to Dewanti el al. (2020) mesh size of 3 inches gill nets with a value of $\mathrm{L} 75 \% \mathrm{Lma}=73.2 \mathrm{~cm}$ are more selective in catching decent size $T$. lepturus fish than gill nets with a mesh size of 2 inches with a value of $\mathrm{L} 75 \% \mathrm{Lmb}=69.2 \mathrm{~cm}$.

Explained again Govender and Al-Qufi (2019), estimation of the selectivity curve in S. longiceps fish has the highest peak of the curve at $14.9 \mathrm{~cm}$ for a mesh size of $3.3 \mathrm{~cm}$ and has increased to $16.9 \mathrm{~cm}$ in mesh size of $3.8 \mathrm{~cm}$. The estimated and observed length-frequency distribution is unimodal. The log-normal selection function shows that the highest selectivity is obtained when the ratio of class length to mesh size is $4.4 \mathrm{~cm}$. The relative abundance of $S$. longiceps fish is estimated to be highest at $16.4 \mathrm{~cm}$ FL. It shows that the optimal gillnet selectivity with a mesh size of $3.8 \mathrm{~cm}$ with a hanging ratio of 0.5 .

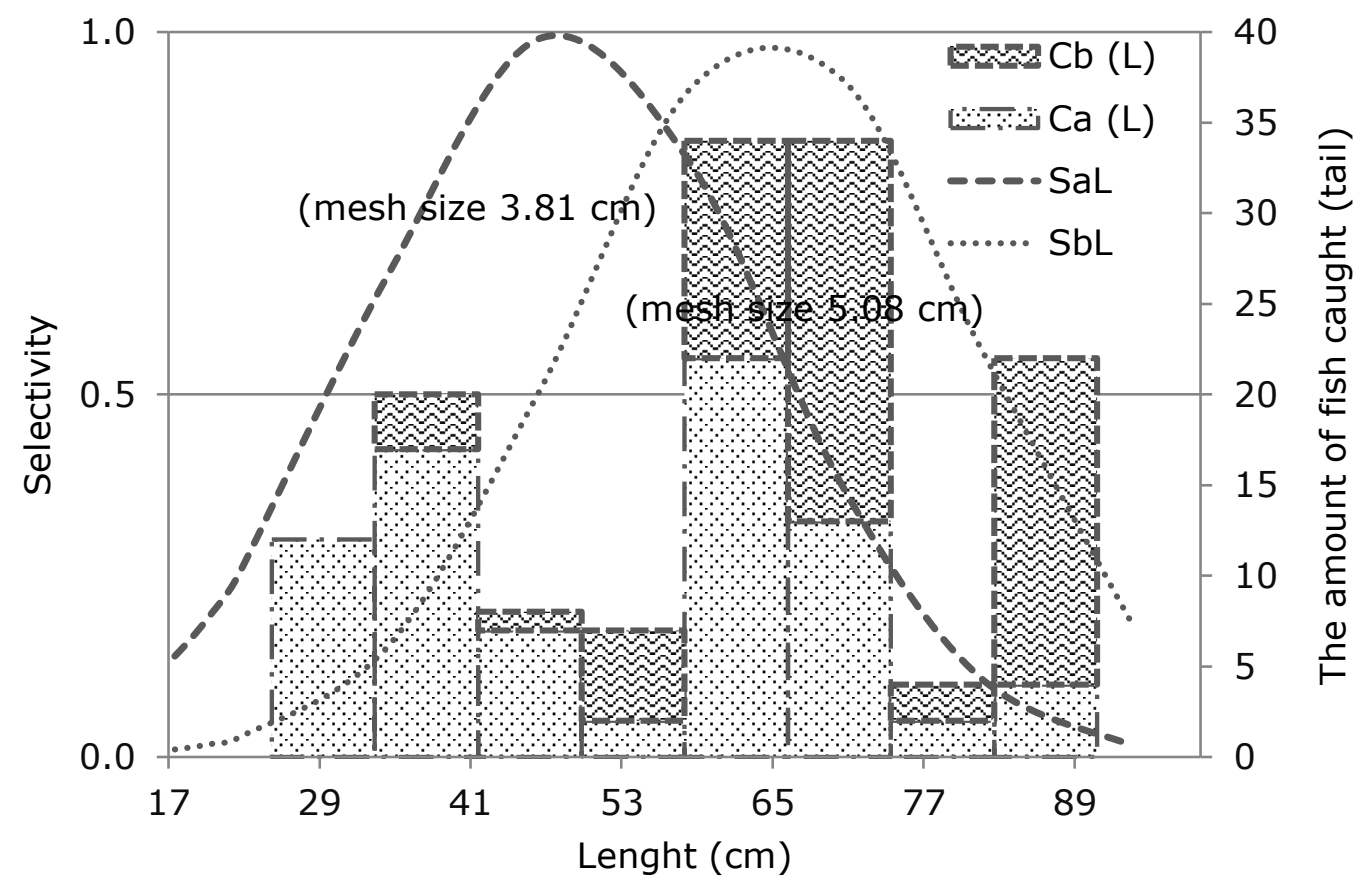

Figure 4. Selectivity curve of Semah fish (Tor tambra) catches in Lirik River using gillnets (mesh size $3.81 \mathrm{~cm}$ and $5.08 \mathrm{~cm}$ ). Information: $\mathrm{Cb}(\mathrm{L})$ and $\mathrm{Ca}(\mathrm{L})$ : The amount caught, SaL and SbL: Mesh size selectivity

The gillnet selectivity curve is like a bell that rises from the left; then, there is a downward slope on the right. Estimates of the selection curve become diverse models, and it can fluctuate among species or size depending on the model chosen to adjust the curve (Balasubramanian et al., 2016). Minuscule fish will not be caught as they can escape from the net so that the probability is zero, fish with a larger size will have a higher probability to a specific size on gilled position, then at a certain point, the size of the fish will go down again due to too large fish just crashing into the fish but not position gilled caught, Minuscule fish will not be caught as they can escape from the net so that the probability is zero, fish with higher size will have higher probabilities until a certain size is caught in the gilled position, then at a certain point the size of the fish will go down again due to too large fish just crashing into the net but caught in entangled position, as the size of his head is bigger than the size of the net. The shape of the selectivity curve only 
applies to the fishing gear of a specific size and type of fish; therefore, if one of the two things changes, the curve will also shift (Spare \& Venema 1999).

According to Klust (1982), Salvanes (1991), Márquez-Farias et al. (2005), and Govender and AlQufi (2019) factors that can influence moves in the selectivity curve, such as low extensibility and elasticity, gender, gonad maturity, the amount of food in the intestine, and the environment (oceanography).

\section{CONCLUSION}

In conclusion, the gillnet operated in Lirik River has an estimated value of selectivity to a 1.5 inch mesh size fish at a length of $48.59 \mathrm{~cm}$ and a mesh size of 2 inches at a length of $64.78 \mathrm{~cm}$. Semah fish (Tor tambra), which have a length outlying under the estimated value of selectivity, will be able to pass through the net without getting entangled, while the fish with a length far upper the selectivity estimation value will entangled.

\section{REFERENCES}

Alverson, D. L., Freeberg, M. H., Murawski, S. A., \& Pope, J. G. (1994). A global assessment of fisheries bycatch and discards (Vol. 339). Food \& Agriculture Org.

Andriyani, H., Brown, A., dan Rengi, P. (2015) Study of sembilang net catching technology using levers in Pematang Sei Baru Village, Tanjung Balai Asahan District, Asahan Regency, North Sumatra Province [Indonesian]. Jurnal Perikanan dan Kelautan, 20(1), 32-40. http://dx.doi.org/10.31258/jpk.20.1.32-42

Balasubramanian, A., Meenakumari, B., Pravin, P., Dhanapal, K., Boopendranath, M. R., \& Erzini, K. (2016). Estimation of gillnet and hook selectivity for Carangoides fulvoguttatus (Forsskal, 1775) captured off Kanyakumari Coast of India. http://krishi.icar.gov.in/jspui/handle/123456789/20353

Dewanti, L. P., Sienna, Y. I., Khan, A., Apriliani, I. M., \& Herawati, H. (2019). Gillnet Selectivity that Catched Trichiurus lepturus in Pangandaran District. ALBACORE Jurnal Penelitian Perikanan Laut, 3(3), 273-281. https://doi.org/10.29244/core.3.3.273-281

Govender, A., \& Al-Oufi, H. (2019). Gillnet selectivity of the Indian oil sardine Sardinella longiceps fished in the Sea of Oman. Journal of Agricultural and Marine Sciences, 24, 1923. http://dx.doi.org/10.24200/jams.vol24iss0pp19-23

Haryono, S. J. (2008). Population and habitat of Tambra Fish, Tor tambroide (Bleeker, 1854) in the waters of the Muller Mountains Region of Central Kalimantan [Indonesian]. Biodiversitas, 9(4), 306-309.

Ishida, K. (1962). Sashi Ami Sentakusei Kyokusen Nitsuite. Hokusui Kenkyu, 20, 20-25.

Kholis, M. N., Jaya, M. M., Hutapea, R. Y., Bangun, T. N. C., \& Heanussa, K. G. (2018). Characteristics of gillnet fishing equipment at the Fish Landing Base Muara Angke, North Jakarta [Indonesian]. SEMAH Jurnal Pengelolaan Sumberdaya Perairan, 2(2). http://ojs.umb-bungo.ac.id/index.php/SEMAHJPSP/article/view/237

Kitahara. (1971). On selecticity curve of gill net. Nippon Suisan Gakkaishi, 37, 289-296.

Klust, G. (1982). Netting materials for fishing gear. Rome: FAO.

Kottelat M., Whitten A. J., Kartikasari S. N., \& Wirjoatmodo, S. (1993). Freshwater fishes of western Indonesia and Sulawesi. Periplus edition. Indonesia.

Márquez-Farias, J. F., Corro-Espinosa, D., Castillo-Géniz, J. L. (2005). Observations on the biology of the Pacific sharpnose shark (Rhizoprionodon longurio, Jordan and Gilbert, 1882), captured in Southern Sinaloa, México. Journal of Northwest Fishery Science, 35, 107-114. https://doi.org/10.2960/J.v35.m506

Martasuganda, S., \& Wahju, R. I. (2011). Calculation of gill net selectivity to skipjack fish with the Matsuoka method approach [Indonesian]. Buletin PSP, 19(3), 284-292. http://journal.ipb.ac.id/index.php/bulpsp/article/view/4163

Matsuoka T. (1995). Sashiami no saizu Sentakusei no Keisanho to sono Suiso Jikken ni Yoru Kensho. Nisuishi 
Millar, R. B., \& Holst, R. (1997). Estimation of gillnet and hook selectivity using log-linear models. ICES Journal of Marine Science, 54(3), 471-477. https://doi.org/10.1006/jmsc.1996.0196

Putri V. L., Kurohman F., \& Fitri, A. D. P. 2018. Technical efficiency and selectivity of gillnet gear to the catch composition in Semarang Waters [Indonesian]. Saintek Perikanan, 13(2), 126132. https://doi.org/10.14710/ijfst.13.2.126-132

Salvanes, A. G. V. (1991). The selectivity for cod (Gadus morhua) in two experimental trammelnets and one gillnet. Fisheries Research, 10(3), 265-285. https://doi.org/10.1016/01657836(91)90080-Y

Smith, H. M. (1945). The freshwater fishes of Thailand or Siam. The Smithsonian Institution, US National Museum. Bulletin, 188.

Sparre, P., \& Venema, S. C. (1999). Introduction to Tropical Fish Stock Assessment Book 1. Translator of the Center for Fisheries Research and Development, Agricultural Research and Development Agency. Jakarta, 438

Subagja, S., Wibowo, A., \& Marson, M. (2009). Growth of semah fish (Tor tambra, Valenciennes, 1842 ) in the waters of the Musi River, South Sumatra [Indonesian]. BAWAL Widya Riset Perikanan Tangkap, 2(4), 133-138. http://dx.doi.org/10.15578/bawal.2.4.2009.133-138

Tawari, R. H. S. (2013). Efficiency of surface gillnets on catches of decaged fishes (Decapterus macarelus) in Kayeli Bay [Indonesian]. Jurnal Amanisal PSP FPIK Unpatti-Ambon, 2(2), 3239.

Weber, M. \& Beaufort, D. (1962). The Fishes of the Indo-Australian Archipelago. Leiden. E. J. B. 